\title{
事前データを利用した可変不感帯幅適応則
}

\author{
小坂学* · 木 村 文 孝*柴 田浩**

\section{Adaptive Law with Variable Dead Zone Width Using a Priori Data}

Manabu KosaKa*, Fumitaka Kimura* and Hiroshi Shibata**

It is useful for control engineers to initialize automatically the tuning parameters of adaptive control by using a priori measured data without any trial and error.

The adaptive law using time varying gain matrix has better convergence rate than the one using fixed gain matrix. In order to be sensitive to characteristic change of control object, it is useful to use variable dead zone width which changes according to magnitude of disturbance.

In this paper, we propose a scaling type law having variable dead zone width and automatic initialization using a priori measured data. We prove a theorem that gives some properties and convergence of the algorithm, and illustrate how to determine the variable width by using data obtained from a priori measurement and at each iteration instant. The variable width is yielded by $\alpha d_{0}(k)$, of which constant $\alpha$ and time variant $d_{0}(k)$ are respectively determined by a priori measured data and data calculated at each iteration.

Furthermore, we apply the above algorithm to identification of an electro-hydraulic servo system and verify the effects.

Key Words: adaptive law, scaling type law, dead zone, variable width, automatic initialization

\section{1.はじめに}

適応制御の実用化を目指すとき，そのメリットとして制御 対象の特性変動への適応が挙げられる。逆にその不安要因と しては，外乱に対するロバスト性と初期調整の困難さが挙げ られる. 漸減ゲイン方式の適応則を持つ適応制御は外乱が存 在してもパラメータの収束が保証されるが, 徐々にゲインが 減少するため特性変動への適応能力が劣化していく. 固定ゲ イン方式の適応則を持つ適応制御は不感帯の導入 ${ }^{1), 2) に よ り ~}$ 外乱が存在してもパラメータの収束が保証されるようになっ た.このようなロバスト適応則の一つである不感带を導入し た適応則 $\left.{ }^{1)}, 2\right)$ は，適応ゲインと不感帯幅を初期調整パラメー タとしてもつ.

しかし適応制御特有のパラメータの初期調整の困難さは, 現場が適応制御に対して抱く不安要因の一つとなっているた め，初期調整の自動化は適応制御の実用化に必須である．不 感帯を導入した適応則 $\left.{ }^{1)}, 2\right)$ は固定ゲイン方式で設計されてい るため時変ゲイン方式であるスケーリング型適応則 ${ }^{3)} に$ 比し

*ダイキン工業 (株) 電子技術研究所 草津市岡本町字大谷 $1000-2$

** 大阪府立大学工学部 堺市学園町 1-1

* Daikin Industries, Ltd., Kusatsu

** College of Engineering, Osaka Prefecture University, Sakai

(Received January 16, 1997)

(Revised March 13, 1998)
て収束性に劣る．また式誤差は入出力信号の大きさと周波数 に依存するため，不感帯幅を外乱の最大值に固定することは 保守的である。

本稿では固定ゲイン方式適応則に比して収束性に優れた時 変ゲイン方式スケーリング型適応則 ${ }^{3)}$ に関して不感帯幅の設 定に適した重み係数の条件式の導出を行い, 収束値の性質に ついて考察する.あらかじめ取得した入出力信号と推定パラ メータの差分に対する制限をもとに不感帯幅と調整ゲインの 初期設定を行うための手順を示す.ささらに入力信号に依存し て不感帯幅を変化させるアルゴリズムを導入することにより， 外乱に対して不感となる領域をできるだけ狭め, 制御対象の 変動に対する感度の向上を図るとともに, 不感帯の初期調整 の自動化手法を示す. 最後に本手順を電気油圧システムに適 用してその有効性を検証する。

本稿の特徵は, 同定対象の事前データから入力に依存する 外乱と入力に依存しない外乱を推定しておき，これをもとに 不感帯幅を調整することにより，高速な収束性と外乱に対す るロバスト性を両立させた適応則を導出したことである．本 適応則を用いて，高速な収束性と外乱に対するロバスト性を 兼ね備えた信号予測, 適応同定などを行い, その精度を向上 させることを狙いとする。

\section{2. 問題の設定}

遅延演算子を $q$ とし、Fig. 1 に示すプロパな離散時間単一 


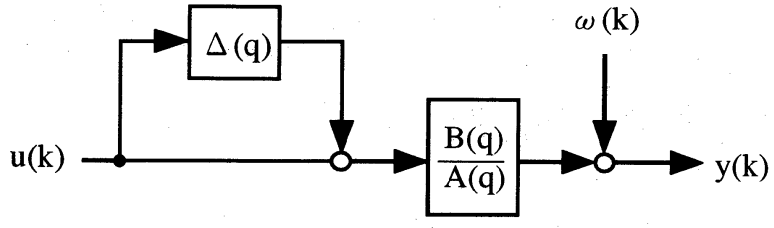

Fig. 1 Control Object

入出力時不変線形系を考える.

$$
\begin{aligned}
y(k)= & (1+\Delta(q)) \frac{B(q)}{A(q)} u(k)+\omega(k) \\
& B(k)=q^{t_{d}}\left(b_{0}+b_{1} q+\cdots+b_{m} q^{m}\right) \\
& A(k)=1+a_{1} q+\cdots+a_{n} q^{n}
\end{aligned}
$$

ここで $k$ はサンプル時刻, $y(k), u(k)$ はそれぞれ出力と入力, $B(q), A(q)$ はそれぞれ $m$ 次の多項式と $n(>m)$ 次のモニッ ク多項式, $t_{d}$ はむだ時間, $\Delta(q), \omega(k)$ はそれぞれ乗法的不 確かさと加法的外部外乱である.

操業時と同程度の入力波形をもつ入出力信号 $\Omega\left(u_{l}, y_{l}\right)$ に 基づいてオフライン最小二乗法などにより推定したパラメー 夕を $\theta_{n}$ とする. $\theta_{n}$ を次式で与える.

$$
\theta_{n}=\left(b_{0}, b_{1}, \cdots, b_{m},-a_{1},-a_{2}, \cdots,-a_{n}\right)^{T}
$$

(1) 式を $\theta_{n}$ を用いて次式で表わす.

$$
\begin{aligned}
y(k)= & \varphi^{T}(k) \theta_{n}+d(k) \\
\varphi(k)= & \left(u\left(k-t_{d}\right), u\left(k-t_{d}-1\right), \cdots\right. \\
& , u\left(k-t_{d}-m\right) \\
& , y(k-1), y(k-2), \cdots, y(k-n))^{T}
\end{aligned}
$$

ここで $\varphi(k)$ は信号べクトルであり, $d(k)$ は外乱である. 次の仮定を設ける.

$\mathrm{A} 1:$ 制御対象の次数 $n, m$ とむだ時間 $t_{d}$ は既知.

A2: 有界かつP.E. 条件を満たす大振幅取得信号 $\Omega\left(u_{l}, y_{l}\right)$ と小振幅取得信号 $\Omega\left(u_{s}, y_{s}\right)$ のサンプル数 $N(<\infty)$ は, 十 分大きい.

A3: 信号ベクトル $\varphi(k)$ は有界かつ P.S. 条件を満たす. 問題は取得した入出力信号に対して次の目的を達成する不 感帯幅と調整ゲインを自動的に求めることである.

O1: 推定パラメータベクトル $\theta(k)$ は一定值に収束する.

O2: 式誤差が不感帯幅の最大值に等しいとき $\theta(k)$ は次 式を満たす。

$$
\frac{\left|\varphi_{l}^{T}(k)(\theta(k+1)-\theta(k))\right|}{\max \left[\left|\varphi_{l}^{T}(k) \theta_{n}\right|\right]} \leq \beta
$$

ただし $\max [\cdot]$ は最大值, |・| は絶対值, 添字 $l$ と $s$ はそれ ぞれ $\Omega\left(u_{l}, y_{l}\right)$ と $\Omega\left(u_{s}, y_{s}\right)$ から得られる量を意味する。

O3: 推定の精度を向上するための, 入力 $u(k)$ に依存し た不感帯の構成.

以下, 3 章にてスケーリング型適応則の重み係数 $\lambda_{2}(k)$ に 不感帯としての役割を持たせるための設計手順を示す. 4 章 では, 適応則のチューニングパラメータの1つである調整ゲ
イン $\alpha$ の初期調整手順を示す.この手順は, あらかじめ取得 しておいた入出力信号 $\Omega\left(u_{l}, y_{l}\right)$ と, 推定パラメー夕の差分 制限である $\beta$ を用いてなされる．5章では，入力信号 $u(k)$ に依存して不感帯幅を変化させる信号 $d_{0}(k)$ の初期調整手順 を示す.この手順は, あらかじめ取得しておいた入出力信号 $\Omega\left(u_{l}, y_{l}\right), \Omega\left(u_{s}, y_{s}\right)$ を用いてなされる，6章において電気 油圧サーボシステムに対する実験結果を示す.

\section{3. 不感帯付きスケーリング型適応則}

本章にてスケーリング型適応則の重み係数 $\lambda_{2}(k)$ に対して 式誤差に対する不感帯としての役割を持たせるための設計手 順を示す.

式誤差 $e(k)$ は次式で与えられる.

$$
e(k)=y(k)-\varphi^{T}(k) \theta(k)
$$

推定パラメータ $\theta(k)$ とゲイン行列 $F(k)$ を次式で更新する.

$$
\begin{gathered}
\theta(k+1)=\theta(k)+ \\
\frac{\lambda_{2}(k) F(k) \varphi(k)}{1+\lambda_{2}(k) \varphi^{T}(k) F(k) \varphi(k)} e(k) \\
F(k+1)=\frac{1}{\lambda_{1}(k)} \\
{\left[F(k)-\frac{\lambda_{2}(k) F(k) \varphi(k) \varphi^{T}(k) F(k)}{\lambda_{1}(k)+\lambda_{2}(k) \varphi^{T}(k) F(k) \varphi(k)}\right]}
\end{gathered}
$$

ただし $0<\lambda_{1}(k) \leq 1,0 \leq \lambda_{2}(k)<\infty$ は重み係数であり， $F(k)$ はゲイン行列で

$$
F(0)=F^{T}(0)>0
$$

である。

$(6) \sim(9)$ 式は $\lambda_{1}(k), \lambda_{2}(k)$ に圥長性を持つ従来のスケーリ ング型適応則 ${ }^{3)}$ である。これは収束性に優れるが4)不感帯を 導入したときの収束性の証明が未完である.

また従来の安定性が証明されている不感帯を導入した適応 則 ${ }^{1)}$ は

$$
\begin{aligned}
\theta(k+1) & =\theta(k)+\frac{\mu \varphi(k)}{1+\varphi^{T}(k) \varphi(k)} D[e(k)] \\
0 & <\mu<2
\end{aligned}
$$

$$
D[e(k)]= \begin{cases}0 & ,|e(k)| \leq \max [|d(k)|] \\ e(k) & ,|e(k)|>\max [|d(k)|]\end{cases}
$$

で与えらるがこれは収束性に劣る ${ }^{4)}$.

このように上記 $2 つ の$ 従来法は収束性と不感帯の導入との 間で一長一短がある。そこで $(7),(8)$ 式の重み係数 $\lambda_{2}(k)$ を 次式で与えることにより, 収束性に優れたスケーリング型適 応則に不感帯が導入できる。

$$
\begin{gathered}
\lambda_{2}(k)=\left\{\begin{array}{cc}
0, & \varphi^{T}(k) \varphi(k)=0 \\
& \text { or }|e(k)| \leq \alpha d_{0}(k) \\
\lambda_{2}^{\prime}(k), & |e(k)|>\alpha d_{0}(k)
\end{array}\right. \\
\lambda_{2}^{\prime}(k)=\frac{\alpha^{2}-1}{\varphi^{T}(k) F(k) \varphi(k)}
\end{gathered}
$$


ただし $\alpha(>1)$ はここでは調整ゲインと呼び，後に説明され る.また $d_{0}(k)$ は $(3)$ 式の外乱 $d(k)$ を用いて次式を満たす ように設定される。

$$
\begin{aligned}
& d_{0}(k) \geq|d(k)| \\
& \max \left[d_{0}(k)\right]=d_{1}=\max [|d(k)|]
\end{aligned}
$$

《定理 1》 取得した入出力信号に対して上述の適応則を適用 することにより目的 O1が達成され，推定パラメータと式誤 差の収束値 $\theta(N), e(N)$ は以下の性質を持つ.

$$
\begin{aligned}
& |e(N)| \leq \alpha d_{1} \\
& \left|\varphi^{T}(N)\left(\theta_{n}-\theta(N)\right)\right| \leq(\alpha+1) d_{1} \\
& \|\tilde{\theta}(N)\|_{2} \leq \frac{p^{1 / 2}(\alpha+1) d_{1}}{\max _{V_{p}}\left[\min \left(\operatorname{eig}\left(V_{p} V_{p}^{T}\right)\right)^{1 / 2}\right]}
\end{aligned}
$$

ただし $p$ は $\theta(k)$ の次数, $\tilde{\theta}(N)=\theta(N)-\theta_{n}, V_{p}$ は $\varphi(k)$ からなる正則な正方行列である . eig(·) は (.) の固有值で ある。

証明を付録に示す。

\section{4. 調整ゲインの初期調整}

本章では，適応則のチューニングパラメータの 1 つである 調整ゲイン $\alpha$ の初期調整手順を示す．この手順は，あらかじ め取得しておいた入出力信号 $\Omega\left(u_{l}, y_{l}\right)$ と, 推定パラメータ の差分制限である $\beta$ を用いてなされる.

$\left|e_{l}(k)\right|$ と $d_{1 l}$ が等しいとき (7) 式より次式を得る.

$$
\begin{aligned}
& \frac{\left|\varphi_{l}^{T}(k)(\theta(k+1)-\theta(k))\right|}{c} \\
= & \frac{\lambda_{2}(k) \varphi_{l}^{T}(k) F(k) \varphi_{l}(k)}{1+\lambda_{2}(k) \varphi_{l}^{T}(k) F(k) \varphi_{l}(k)} \frac{d_{1 l}}{c} \\
& c=\max \left[\left|\varphi_{l}^{T}(k) \theta_{n}\right|\right]
\end{aligned}
$$

$\lambda_{2}(k) \neq 0$ のとき $(10)$ 式より次式を得る.

$$
1+\lambda_{2}(k) \varphi_{l}^{T}(k) F(k) \varphi_{l}(k)=\alpha^{2}
$$

上式を用いると次式が得られる.

$$
\begin{aligned}
& \frac{\lambda_{2}(k) \varphi_{l}^{T}(k) F(k) \varphi_{l}(k)}{1+\lambda_{2}(k) \varphi_{l}^{T}(k) F(k) \varphi_{l}(k)} \frac{d_{1 l}}{c}=\frac{\alpha^{2}-1}{\alpha^{2}} \frac{d_{1 l}}{c} \\
& \text { ここで調整ゲイン } \alpha^{2} \text { を, } \\
& \alpha^{2}=\frac{1}{1-\beta c / d_{1 l}}
\end{aligned}
$$

ととると (15), (18) 式より目的 $\mathrm{O} 2$ が満たされることがわ かる。

ここでゲイン行列 $F(k)$ の初期値による影響を考察する. 適応則 $(7),(8)$ に $(10),(17)$ 式を代入して次式を得る.

$$
\begin{gathered}
\theta(k+1)=\theta(k)+ \\
\frac{\alpha^{2}-1}{\alpha^{2}} \frac{F(k) \varphi(k)}{\varphi^{T}(k) F(k) \varphi(k)} e(k) \\
F(k+1)=\frac{1}{\lambda_{1}(k)}[F(k)- \\
\left.\frac{\left(\alpha^{2}-1\right) F(k) \varphi(k) \varphi^{T}(k) F(k)}{\left(\lambda_{1}(k)+\alpha^{2}-1\right) \varphi^{T}(k) F(k) \varphi(k)}\right]
\end{gathered}
$$

$F(k)$ の初期值を $F(0)=\gamma F_{0}$ としたとき $(21)$ 式よりゲイ ン行列が $\gamma$ 倍されるが $(20)$ 式の第 2 項は $\gamma$ に依存しないの で, $\theta(k)$ はゲイン行列の初期值に影響されない.

\section{5. 不感帯幅の初期調整}

本章では, 入力信号 $u(k)$ に依存して幅が変化する不感帯 を構成し，適応則のチューニングパラメータの1つである $d_{0}(k)$ の初期調整手順を示す。この手順は, 大振幅事前デー 夕 $\Omega\left(u_{l}, y_{l}\right)$ と小振幅事前デー夕 $\Omega\left(u_{s}, y_{s}\right)$ を用いてなされる. 取得した入出力信号を $(3)$ 式に適用して求まる外乱 $d_{l}(k)$ を 用いて $(11)$ 式を満たす $d_{0}(k)$ を推定する.

$d(k)$ の性質を Fig. 1 の乗法的不確かさ $\Delta(q)$ と出力部加法 的外乱 $\omega(k)$ を導入して考察する. $B(q) / A(q)$ は制御対象の ノミナルモデル (公称值) で電気油圧サーボシステムの計算 時間を短縮するため一次遅れとしている．無視した高次特性 である乗法的不確かさ $\Delta(q)$ は電気油圧システムの油の乱流, 高次特性, 摩擦などであり, 入力の大きさと周波数に依存す。 る. 出力部加法的外乱 $\omega(k)$ は電気油圧システムの DA 変換 器の量子化誤差, スライド位置検出用パルスカウンタ, アン プなどのノイズであり，入力 $u(k)$ に依存しない.

経験的に乗法的不確かさ $\Delta(q)$ のゲインは高周波域で大き く，低周波域で小さいことが知られている.

(1) 式から次式を得る.

$$
\begin{aligned}
A(q) y(k) & =B(q) u(k)+\Delta(q) B(q) u(k)+A(q) \omega(k) \\
y(k) & =\varphi^{T}(k) \theta_{n}+d(k) \\
d(k) & =\Delta(q) B(q) u(k)+A(q) \omega(k)
\end{aligned}
$$

(22) 式の $d(k)$ の第一項は入力の大きさと周波数に依存する ことから次式のように一次系で上界を与える.

$$
\begin{aligned}
& |\Delta(q) B(q) u(k)| \\
\leq & \left|q^{t_{d}}\{g(1-q)+h\} u(k)\right| \\
= & \left|g\left\{u\left(k-t_{d}\right)-u\left(k-t_{d}-1\right)\right\}+h u\left(k-t_{d}\right)\right|(23)
\end{aligned}
$$

(22) 式の第二項は外部外乱に依存するため, 次式を満たす 定数 $d_{2}$ ，を導入する.

$$
d_{2}=\max |A(q) \omega(k)|
$$

このとき $d_{1 s}\left(\geq d_{2}\right)$ を導入して次式で定義した $d_{0}(k)$ は次 のように(11) 式を満たす.

$$
\begin{aligned}
d_{0}(k)= & \left\{\begin{array}{cc}
d_{0}^{\prime}(k), & d_{0}^{\prime}(k) \leq d_{1 l} \\
d_{1 l}, & d_{0}^{\prime}(k)>d_{1 l}
\end{array}\right. \\
d_{0}^{\prime}(k)= & g\left|u_{l}\left(k-t_{d}\right)-u_{l}\left(k-t_{d}-1\right)\right| \\
& +h\left|u_{l}\left(k-t_{d}\right)\right|+d_{1 s} \\
\geq & \left|q^{t_{d}}\{g(1-q)+h\} u_{l}(k)\right|+d_{1 s} \\
\geq & \left|\Delta(q) B(q) u_{l}(k)+A(q) \omega(k)\right|(\because(23),(24)) \\
= & \left|d_{l}(k)\right|
\end{aligned}
$$

上式で定める $d_{0}(k)$ は外乱の性質により大きさが変化する ため, 外乱に対して不感となる領域を狭め, 従来の不感帯幅 


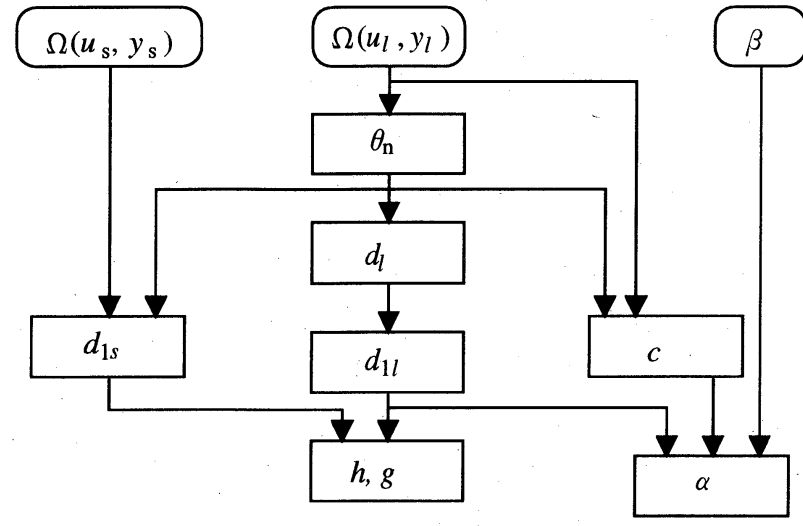

Fig. 2 flow of this method

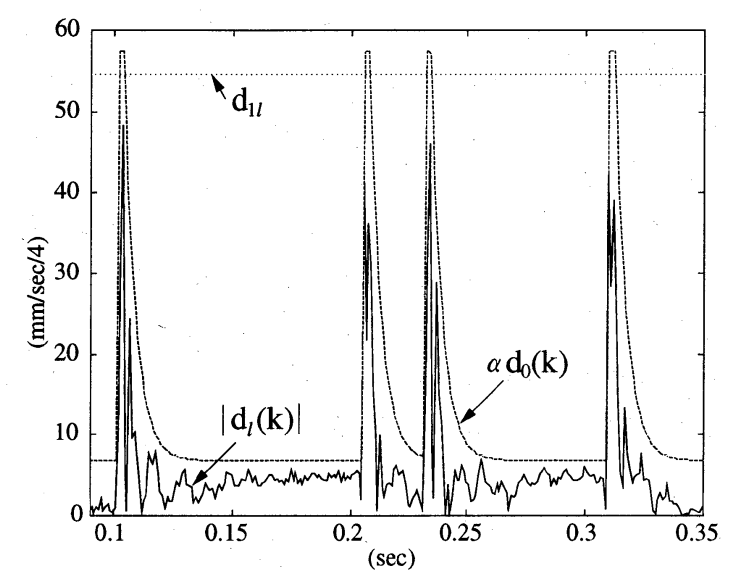

Fig. 3 The disturbance $\left|d_{l}(k)\right|$, the dead zone $d_{1 l}$ and $\alpha d_{0}(k)$

$d_{0}(k)=\max \left[\left|d_{l}(k)\right|\right]^{1), 2)}$ よりも保守性が軽減され, それだ け制御対象の変動に対する精度を向上させている。

$(25)$ 式の $g$ と $h$ を大振幅応答 $\Omega\left(u_{l}, y_{l}\right)$ をもとに (11) 式 を拘束条件, $\min \left|d_{0}(k)-d(k)\right|$ を評価としたイタレーショ ンにより求める. 以上の調整ゲイン $\alpha$ と不感帯 $d_{0}(k)$ の初 期調整を行う手順を Fig. 2 に示しておく.

$(25)$ 式による $d_{0}(k)$ を Fig. 3 に示す. 同図において外乱 $\left|d_{l}(k)\right|$, 外乱の最大值 $d_{1 l}$ と構成した不感帯幅 $\alpha d_{0}(k)$ をそ れぞれ実線, 破線と点線で示す。従来法 ${ }^{1)}$ の不感帯幅 $d_{1 l}$ に 比して，ほとんどの時間において $\left|d_{l}(k)\right| \leq \alpha d_{0}(k) \leq d_{1 l}$ を 満足しているので不感帯幅に対する保守性が軽減され，制御 対象の特性変動に対する推定の感度が向上していることがわ かる.

\section{6. 電気油圧システムでの実験結果}

\section{1 実験装置}

初期調整を自動的に行える本適応則を電気油圧サーボシス テムに適用した。 このシステムは, ダイレクト電磁比例弁と 油圧シリンダで構成される。シリンダ位置はパルスカウンタ によって検出され，ディジタルコントローラに入力されて， オイラー近似により速度 $y(k)$ が算出される。比例弁はマイ
ナーループを有していて, スプール位置が差動トランスとバ ルブドライバによって制御される。電気油圧システムは動作 条件や負荷に依存して特性の変動が起こり, 非線形特性を有 するため, 適応則の初期調整が困難である.

\section{2 初期調整}

あらかじめ定めた諸量は以下のとおりである。 パラメータ差分制限 $\quad \beta=0.05$

入出力信号のサンプル数 $\quad N=1000$

入出力信号のサンプル時間 $t s=0.004(\mathrm{sec})$

比例電磁弁の動作電圧が $\pm 5000(\mathrm{mV})$ であることから, 大 振幅と小振幅での同定入力の振幅 $u_{m}$ をそれぞれ $4000(\mathrm{mV})$ と $100(\mathrm{mV})$ とした.

操業時と同程度の入力波形 $u_{l}$ として $\mathrm{M}$ 系列信号にカット オフ周波数 $50(\mathrm{rad} / \mathrm{sec})$ の低域通過フィル夕をかけた信号を 用いて取得した大振幅入出力信号 $\Omega\left(u_{l}, y_{l}\right)$ から対象 $P(q)$ の 構造を次のように定めた。

$$
\begin{aligned}
& P(q)=q^{t_{d}} \frac{b_{0}}{1+a_{1} q}, t_{d}=3 \\
& \text { オフライン最小二乗法により } \theta_{n}=\left(b_{0}-a_{1}\right)^{T} \text { として次の } \\
& \text { パラメータを得た. } \\
& \theta_{n}=(12.630 .6220)^{T}
\end{aligned}
$$

取得した大振幅入出力信号 $\Omega\left(u_{l}, y_{l}\right)$ に基づいて (16) 式よ り $c$ を，(11) 式から $d_{1 l}$ を算出した.

$$
\begin{aligned}
& c=109.3 \\
& d_{1 l}=54.46(\mathrm{~mm} / \mathrm{sec} / 4)
\end{aligned}
$$

これより $d_{1 l} / c=0.4981$ となり, 式誤差 $d_{1 l}$ のとき $\left|\varphi_{l}^{T}(k)(\theta(k+1)-\theta(k))\right| / c$ が $5 \%$ 変動するように $\beta=0.05$ と設定した。このとき (19) 式から

$$
\alpha^{2}=1.112
$$

を得た。

取得した小振幅入出力信号 $\Omega\left(u_{s}, y_{s}\right)$ ）に基づいて (11) 式よ り $d_{1 s}$ を算出した.

$$
d_{1 s}=6.436
$$

次に $(25)$ 式の $g$ と $h$ を求める. 取得した大振幅入出力信 号に基づいて (3) 式により求めた外乱 $d_{l}(k)$ を Fig. 3 に示す. 大振幅入出力信号に基づいて (25) 式により(11) 式を拘束 条件, $\min \left|d_{0}(k)-d(k)\right|$ を評価とするイタレーションを行 い $h$ を算出した.

$$
h=0.009095
$$

上式の $h$ を用いて大振幅入出力信号に基づいて (25) 式によ り(11) 式を拘束条件, $\min \left|d_{0}(k)-d(k)\right|$ を評価として $g$ に 関するイタレーションを行い, 次の值を得た.

$$
g=65.87
$$

以上から求めた $d_{1 l}, d_{1 s}, h, g$ と入力 $u\left(k-t_{d}\right), u\left(k-t_{d}-1\right)$ を (25) 式に代入して各 $k$ 時刻の不感帯幅 $d_{0}(k)$ を得る。本 


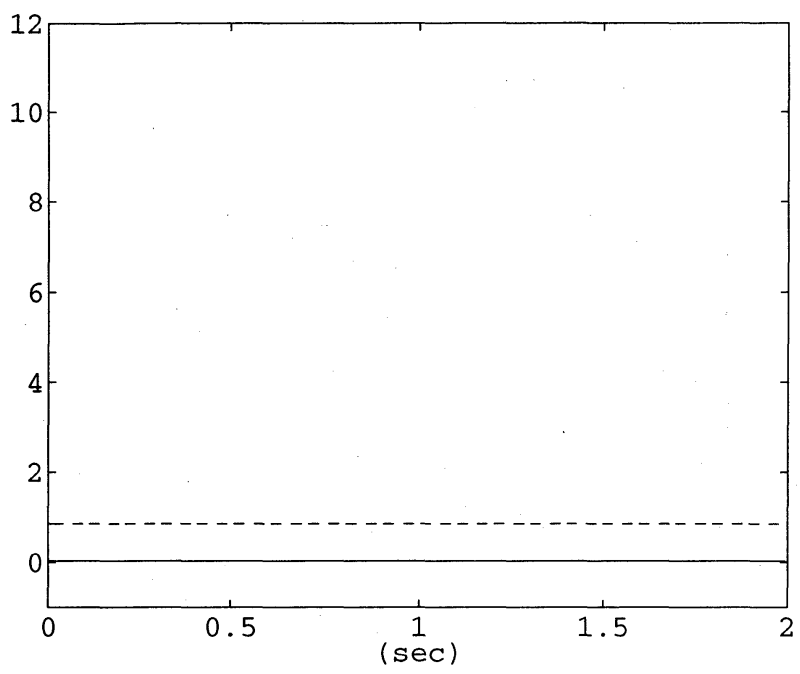

Fig. $4 \theta(k)$ by Samson's method with $d_{1}$

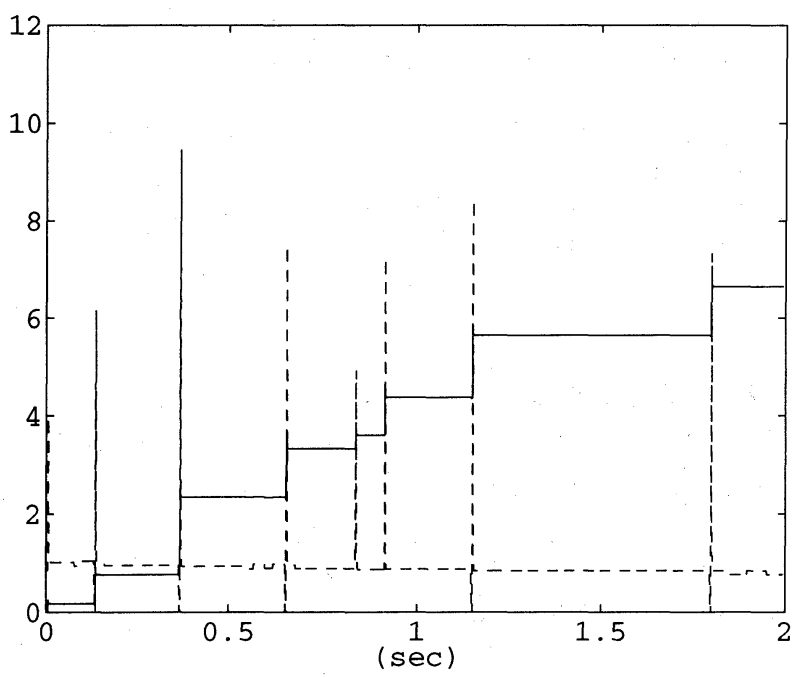

Fig. $5 \theta(k)$ by Samson's method with $d_{0}(k)$

手順から最大振幅 $4000(\mathrm{mV})$ の取得した応答は Fig. 3 に示 すように (11) 式を満足する.

\section{3 パラメータ推定実験}

前節までに求めた諸量をもとに推定実験を行った。パ ラメー夕の初期値は $\theta(0)=\left(\begin{array}{ll}0 & 0\end{array}\right)^{T}$, ゲイン行列の初期 值 $F(0)=I^{2 \times 2}$ とした. 有限語長演算を行った場合, $\lambda_{1}(k)=1$ が続いたときに発生する $F(k)$ のアンダーフ ロー ${ }^{3)}$ と $\lambda_{2}(k)=0$ かつ $\lambda_{1}(k)<1$ が続いたときに発生する $F(k)$ のオーバーフロー3)を避けるために, $\lambda_{2}(k)=0$ のと き $\lambda_{1}(k)=1, \lambda_{2}(k)=0$ でないとき $\lambda_{1}(k)=0.9$ に設定した. (11) 式の固定不感帯幅 $d_{1}$ を導入した固定ゲイン方式適応 則 ${ }^{1)}$, (25) 式の時変不感帯幅 $d_{0}(k)$ を導入した固定ゲイン 方式適応則 ${ }^{1)}, d_{0}(k)$ を導入した $(6) \sim(10)$ 式の時変ゲイン 方式適応則による結果を，それぞれ Fig. 4, Fig. 5, Fig. 6 に示す．各々の図の実線と破線はそれぞれ $\hat{\theta}(k)$ の第 1 , 第 2 要素である. 固定ゲイン方式適応則の調整パラメー夕 $\mu$ は, 試行錯誤により最も良好な結果が得られるように調整されて

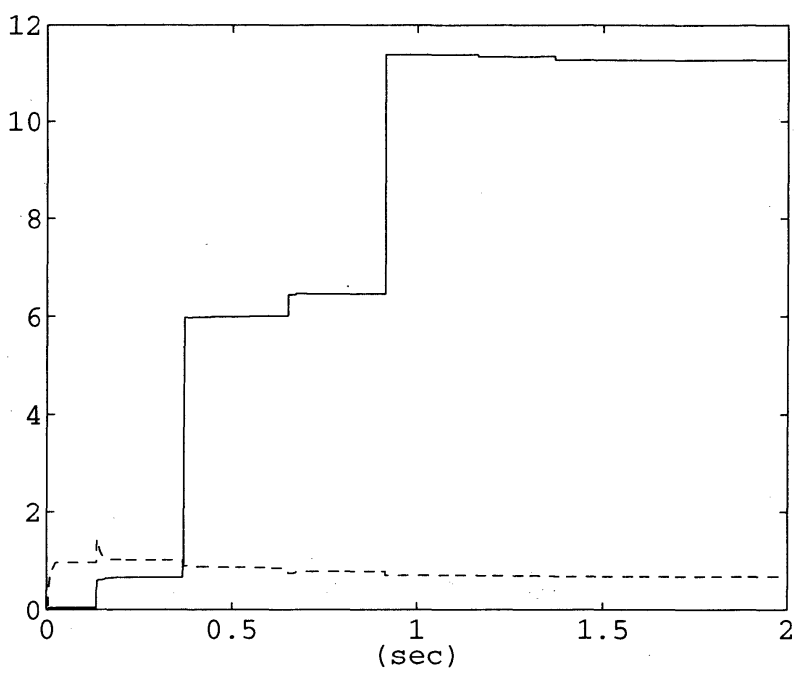

Fig. $6 \theta(k)$ by our method

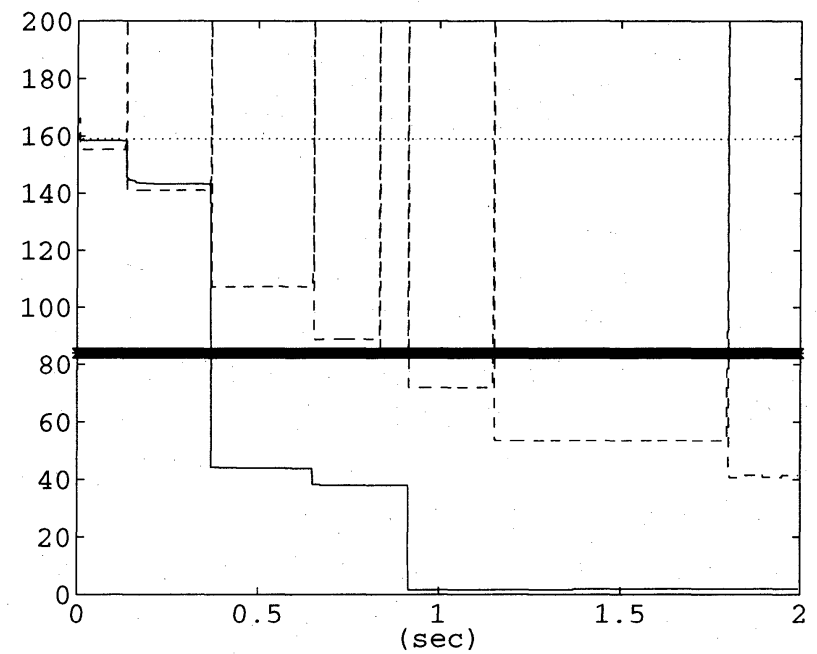

Fig. $7 \quad \tilde{\theta}^{T}(k) \tilde{\theta}(k)$

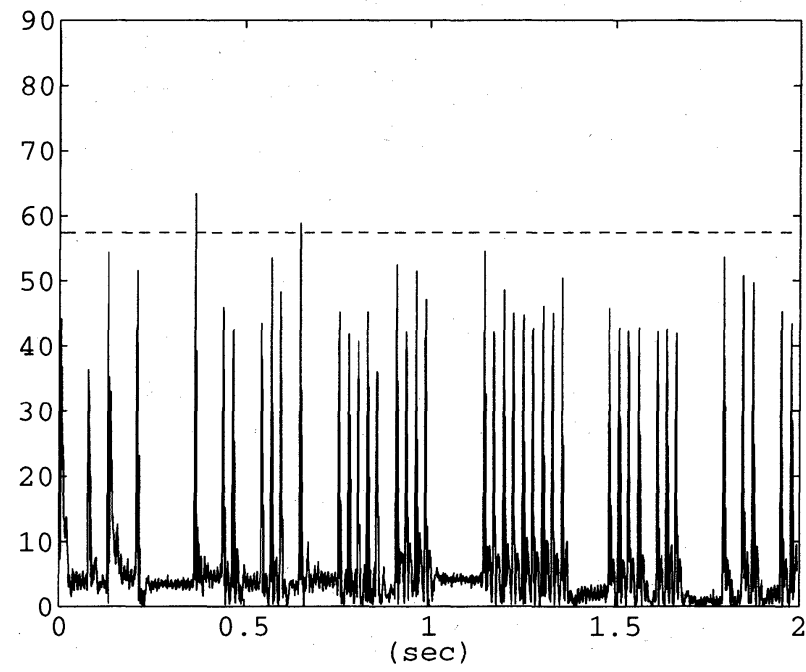

Fig. $8|e(N)| \leq \alpha d_{1}$ by our method

いる. Fig. 6 より本方式に対して目的 $\mathrm{O} 1$ の $\theta(k)$ の一定值へ 


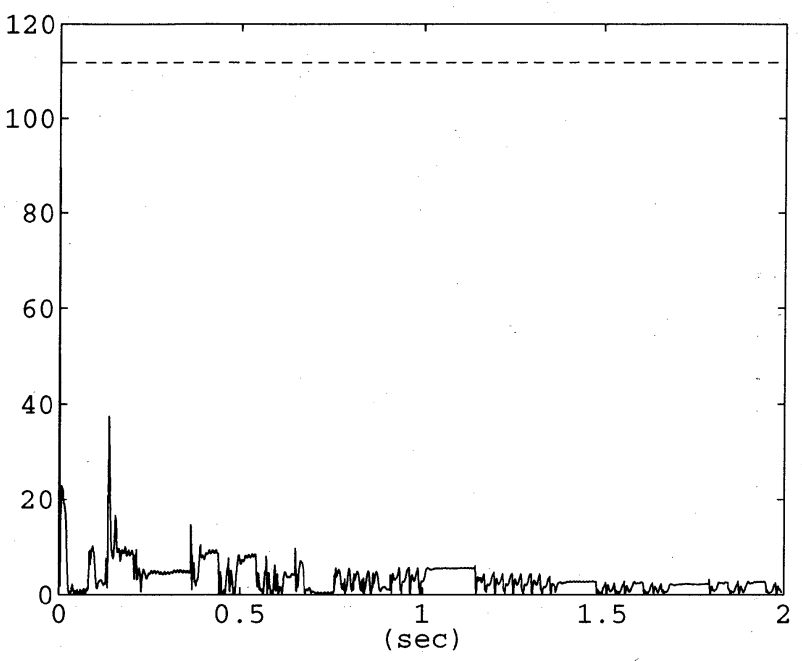

Fig. $9\left|\varphi^{T}(k)\left(\theta_{n}-\theta(N)\right)\right| \leq(\alpha+1) d_{1}$ by our method

Table 1 Average of loutput error|

\begin{tabular}{|c||l|l|l|l|}
\hline $\begin{array}{l}\text { Estimated } \\
\text { parameter }\end{array}$ & $\begin{array}{l}\hat{\theta}(N) \text { of } \\
\text { Fig. } 4\end{array}$ & $\begin{array}{l}\hat{\theta}(N) \text { of } \\
\text { Fig. } 5\end{array}$ & $\begin{array}{l}\hat{\theta}(N) \text { of } \\
\text { Fig. 6 }\end{array}$ & $\theta_{n}$ \\
\hline$E$ & 85.21 & 18.54 & 9.039 & 9.468 \\
\hline
\end{tabular}

の収束性が確認できる.

Fig. 7 に上述の 3 つの適応則における $\tilde{\theta}^{T}(k) \tilde{\theta}(k)$ と (14) 式の右辺の值をそれぞれ点線，破線，実線，太線で示す. Fig. 4 と Fig. 5 の比較と Fig. 7 方ら時変な不感带幅 $d_{0}(k)$ の固定不 感带幅 $d_{1}$ に対する優位性が確認できる. Fig. 5 と Fig. 6 の 比較と Fig. 7 から時変ゲイン方式適応則の固定ゲイン方式適 応則に対する優位性が確認できる。

次に (12),(13),(14) 式を評価した結果をそれぞれ Fig. 8, Fig. 9, Fig. 7 に示す. それぞれの式の評価項目（左辺）の信 号を実線で示し, (12),(13) 式の右辺の值と (14) 式の右辺の 值をそれぞれ破線と太線で示す.3つの図から (12),(13),(14) 式が満たされることが確認でき，理論通りの結果を得た.

Table 1 に $\theta_{n}$ と Fig. 4 , Fig. 5 , Fig. 6 の 3 つの適応則の $\hat{\theta}(N)$ を用いて算出した出力誤差の絶対值の平均値 $E$ を示す. Table 1 より本適応則の推定結果は, 最も優れていることが 確認できる。

\section{7. まとめ}

本稿では固定ゲイン方式適応則に比して収束性に優れた時 変ゲイン方式スケーリング型適応則 ${ }^{3)}$ に対して不感带幅の調 整に適した重み係数の条件式の導出を行った. 従来よりも感 覚的にわかりやすい指標である推定パラメータの差分に対す る制限を設定すれば，あらかじめ取得した大振幅と小振幅の 2 つの入出力信号に基づいて不感帯幅と調整ゲインに関する 初期パラメー夕設定を行うことができ，その手順を示した。 これをもとに不感帯幅を入力信号に依存して変化させること により不感帯幅に対する保守性の軽減化を達成した．最後に 本手順を電気油圧システムに適用してその有効性を確認した。

理論の構成上，操業時に発生する外乱を含む事前デー夕
$\Omega\left(u_{l}, y_{l}\right)$ の取得が可能であることと, $\Delta(q), A(q), B(q)$ に依 存する $(22)$ 式の外乱 $d(k)$ の上界が不变であることを仮定し ている. 本法は，実用的には Fig. 2 のパラメー夕が決定でき るような場合に適用可能である. 確率統計理論から, どのよ うな不確かさや外乱のもとで，それが理論的に保証されるか は今後の検討課題である。しかし不感帯幅を外乱の最大値に 固定する従来法 1),2) よりも, 可変不感带幅を持つ本法の方 が外乱に対して不感な領域を狭めることができるので, 本法 は従来法よりも優位であり，このことは実験結果によっても 示された. Fig. 2 の諸量が変わらないようなパラメー夕変化 に対しては本法が適用でき，そのときは適応制御への応用も 考えられる。

\section{参 考 文 献}

1) C. Samson: Stability analysis of adaptively controlled systems subject to bounded disturbanceds,Automatica, Vol.19, No.1, pp.81-86, 1983.

2) L. S. Narendra and A. M. Annaswamy: Stable Adaptive Systems, Chap. 2, Prentice Hall (1989)

3）新中: 適応アルゴリズム, 産業図書 $(1990)$

4）新中，ほか: 適応制御の実用化に向けて, 計測と制御, 32-12, 1018/1019 (1993)

5）児玉, 須田: システム制御のためのマトリクス理論, 計測自動 制御学会 (1978)

\section{《付 録》}

\section{A. 定理 1 の証明}

文献 3)に沿って以下に一般的な離散型沉一般化適応則に 関して漸近安定性の証明を行う。

$$
\begin{aligned}
& e(k)=y(k)-\varphi^{T}(k) \theta(k) \\
& \theta(k+1)=\theta(k)+\mu_{0}(k) F(k) \varphi(k) e(k) \\
& F(k+1)=\frac{1}{\lambda_{1}(k)} \\
& {\left[F(k)-\frac{\lambda_{2}(k) F(k) \varphi(k) \varphi^{T}(k) F(k)}{\lambda_{1}(k)+\lambda_{2}(k) \varphi^{T}(k) F(k) \varphi(k)}\right]} \\
& 0<\lambda_{1}(k) \leq 1,0 \leq \lambda_{2}(k)<\infty \\
& \quad \frac{1-\left(1+\lambda_{2}(k) \varphi^{T}(k) F(k) \varphi(k)\right)^{-1 / 2}}{\varphi^{T}(k) F(k) \varphi(k)} \\
& <\mu_{0}(k) \quad \\
& <\frac{1+\left(1+\lambda_{2}(k) \varphi^{T}(k) F(k) \varphi(k)\right)^{-1 / 2}}{\varphi^{T}(k) F(k) \varphi(k)}
\end{aligned}
$$

パラメータ $\theta_{n}$ と推定パラメータ $\theta(k)$ との差を $\tilde{\theta}(k)$ と置く.

$$
\tilde{\theta}(k)=\theta(k)-\theta_{n}
$$

(A. 1),(A. 5) 式より次式を得る.

$$
\tilde{\theta}(k+1)=\tilde{\theta}(k)+\mu_{0}(k) F(k) \varphi(k) e(k)
$$

(A. 2) 式に逆行列補題を適用して次式を得る.

$$
F^{-1}(k+1)=\lambda_{1}(k) F^{-1}(k)+\lambda_{2}(k) \varphi(k) \varphi^{T}(k)
$$


(3),(6) 式より次式を得る.

$$
\tilde{\theta}^{T}(k) \varphi(k)=-e(k)+d(k)
$$

$F(k)>0$ より $F^{-1}(k) \geq 0$ であるので次の非負関数 $V(k)$ を リアプノフ関数の候補とする。

$$
V(k)=\tilde{\theta}^{T}(k) F^{-1}(k) \tilde{\theta}(k)
$$

$V(k)$ の増分を $\Delta V(k)=V(k+1)-V(k)$ とする.

$$
\begin{aligned}
& \Delta V(k) \\
& =V(k+1)-V(k) \\
& =\tilde{\theta}^{T}(k+1) F^{-1}(k+1) \tilde{\theta}(k+1)-\tilde{\theta}^{T}(k) F^{-1}(k) \tilde{\theta}(k) \\
& =\tilde{\theta}^{T}(k+1)\left\{\lambda_{1}(k) F^{-1}(k)+\lambda_{2}(k) \varphi(k) \varphi^{T}(k)\right\} \\
& \tilde{\theta}(k+1) \\
& (\because(A .7)) \\
& -\left\{\tilde{\theta}(k+1)-\mu_{0}(k) F(k) \varphi(k) e(k)\right\}^{T} F^{-1}(k) \\
& \left\{\tilde{\theta}(k+1)-\mu_{0}(k) F(k) \varphi(k) e(k)\right\} \quad(\because(A .6)) \\
& =\lambda_{1}(k) \tilde{\theta}^{T}(k+1) F^{-1}(k) \tilde{\theta}(k+1) \\
& +\lambda_{2}(k)\left\{\tilde{\theta}^{T}(k+1) \varphi(k)\right\}^{2} \\
& -\left\{\tilde{\theta}^{T}(k+1) F^{-1}(k) \tilde{\theta}(k+1)\right. \\
& -2 \mu_{0}(k) e(k) \varphi^{T}(k) F(k) F^{-1}(k) \tilde{\theta}(k+1) \\
& \left.+\mu_{0}^{2}(k) e^{2}(k) \varphi^{T}(k) F(k) \varphi(k)\right\} \\
& =-\left(1-\lambda_{1}(k)\right) \tilde{\theta}^{T}(k+1) F^{-1}(k) \tilde{\theta}(k+1) \\
& +\lambda_{2}(k)\left\{\tilde{\theta}^{T}(k+1) \varphi(k)\right\}^{2} \\
& +2 \mu_{0}(k) e(k) \varphi^{T}(k) \tilde{\theta}(k+1) \\
& -\mu_{0}^{2}(k) e^{2}(k) \varphi^{T}(k) F(k) \varphi(k) \\
& =-\left(1-\lambda_{1}(k)\right) \tilde{\theta}^{T}(k+1) F^{-1}(k) \tilde{\theta}(k+1) \\
& +\lambda_{2}(k)\left\{\left(\tilde{\theta}(k)+\mu_{0}(k) F(k) \varphi(k) e(k)\right)^{T} \varphi(k)\right\}^{2} \\
& +2 \mu_{0}(k) e(k) \varphi^{T}(k)\left\{\tilde{\theta}(k)+\mu_{0}(k) F(k) \varphi(k) e(k)\right\} \\
& -\mu_{0}^{2}(k) e^{2}(k) \varphi^{T}(k) F(k) \varphi(k) \\
& (\because(A .6)) \\
& =-\left(1-\lambda_{1}(k)\right) \tilde{\theta}^{T}(k+1) F^{-1}(k) \tilde{\theta}(k+1) \\
& +\lambda_{2}(k)\{-e(k)+d(k)+ \\
& \left.\mu_{0}(k) \varphi^{T}(k) F(k) \varphi(k) e(k)\right\}^{2} \\
& +2 \mu_{0}(k) e(k) \\
& \left\{-e(k)+d(k)+\mu_{0}(k) \varphi^{T}(k) F(k) \varphi(k) e(k)\right\} \\
& -\mu_{0}^{2}(k) e^{2}(k) \varphi^{T}(k) F(k) \varphi(k) \quad(\because(A .8)) \\
& =-\left(1-\lambda_{1}(k)\right) \tilde{\theta}^{T}(k+1) F^{-1}(k) \tilde{\theta}(k+1) \\
& +\lambda_{2}(k) e^{2}(k)\left(1-\mu_{0}(k) \varphi^{T}(k) F(k) \varphi(k)\right)^{2} \\
& +\lambda_{2}(k)\left[-2 e(k) d(k)\left(1-\mu_{0}(k) \varphi^{T}(k) F \varphi(k)\right)\right. \\
& \left.+d^{2}(k)\right] \\
& -2 \mu_{0} e^{2}(k)\left(1-\mu_{0}(k) \varphi^{T}(k) F(k) \varphi(k)\right) \\
& +2 \mu_{0}(k) e(k) d(k) \\
& -\mu_{0}^{2}(k) e^{2}(k) \varphi^{T}(k) F(k) \varphi(k)
\end{aligned}
$$

$$
\begin{aligned}
= & -\left(1-\lambda_{1}(k)\right) \tilde{\theta}^{T}(k+1) F^{-1}(k) \tilde{\theta}(k+1) \\
& -e^{2}(k)\left[\mu_{0}(k)\left(2-\mu_{0}(k) \varphi^{T}(k) F(k) \varphi(k)\right)\right. \\
& \left.-\lambda_{2}(k)\left(1-\mu_{0}(k) \varphi^{T}(k) F(k) \varphi(k)\right)^{2}\right] \\
& -2 e(k) d(k)\left[\lambda_{2}(k)\left(1-\mu_{0}(k) \varphi^{T}(k) F(k) \varphi(k)\right)\right. \\
& \left.-\mu_{0}(k)\right] \\
+ & \lambda_{2}(k) d^{2}(k)
\end{aligned}
$$

(A. 3),(A. 4) 式より (A. 10) 式の第 1 項と第 2 項は準負で ある. 外乱 $d(k)$ が存在するとき (A. 10) 式の第 3 項は不定で あり第 4 項は準正であるので $\Delta V(k)$ の準負が保証されない. (A. 10) 式で利用不可能な信号は $d(k)$ と $\tilde{\theta}(k)$ であるが $\tilde{\theta}(k)$ に 関する第 1 項は準負である. 第 $2 \sim 4$ 項までの準負すなわち $\Delta V(k)$ の準負を保証するためには次の関係式が必要である.

$$
-p_{1} e^{2}(k)+2 p_{2} d(k) e(k)+p_{3} d^{2}(k) \leq 0
$$
ただし

$$
\begin{aligned}
p_{1}= & \mu_{0}(k)\left(2-\mu_{0}(k) \varphi^{T}(k) F(k) \varphi(k)\right) \\
& -\lambda_{2}(k)\left(1-\mu_{0}(k) \varphi^{T}(k) F(k) \varphi(k)\right)^{2}>0 \\
p_{2}= & -\left[\lambda_{2}(k)\left(1-\mu_{0}(k) \varphi^{T}(k) F(k) \varphi(k)\right)-\mu_{0}(k)\right] \\
p_{3}= & \lambda_{2}(k) \geq 0
\end{aligned}
$$

そこで $d_{0}(k)(\geq|d(k)|)$ が既知であるならば (A. 12) 式を満 たすとき $\mu_{0}(k)$ を (A. 13) 式で設定することにより第 $2 \sim 4$ 項までの準負すなわち $\Delta V(k)$ の準負が保証される.

$$
\begin{aligned}
& d_{0}(k) \frac{p_{2}-\left(p_{2}^{2}+p_{1} p_{3}\right)^{1 / 2}}{p_{1}} \\
\leq & e(k) \\
\leq & d_{0}(k) \frac{p_{2}+\left(p_{2}^{2}+p_{1} p_{3}\right)^{1 / 2}}{p_{1}} \\
& \mu_{0}(k)=0,(\mathrm{~A} .12) \text { を満たすとき }
\end{aligned}
$$

しかし (A. 12) 式の計算負荷が実用上大きい. そこで $\mu_{0}(k)$ を次のように陽形式一般化適応則 ${ }^{3)}$ に限定する.

$$
\begin{aligned}
& \mu_{o}(k)=\frac{\mu_{1}(k)}{1+\mu_{1}(k) \varphi^{T}(k) F(k) \varphi(k)} \\
& , 0<\lambda_{1}(k)<1,0 \leq \lambda_{2}(k)<2 \mu_{1}(k)
\end{aligned}
$$

上式を (A.10) 式に代入する.

$$
\begin{gathered}
\Delta V(k)=-\left(1-\lambda_{1}(k)\right) \tilde{\theta}^{T}(k+1) F^{-1}(k) \tilde{\theta}(k+1) \\
-e^{2}(k) \frac{2 \mu_{1}(k)-\lambda_{2}(k)+\mu_{1}^{2}(k) \varphi^{T}(k) F(k) \varphi(k)}{\left(1+\mu_{1}(k) \varphi^{T}(k) F(k) \varphi(k)\right)^{2}} \\
-\frac{2 e(k) d(k)\left(\lambda_{2}(k)-\mu_{1}(k)\right)}{1+\mu_{1}(k) \varphi^{T}(k) F(k) \varphi(k)} \\
+\lambda_{2}(k) d^{2}(k)
\end{gathered}
$$

(A. 14), (A. 15) 式より $\mu_{1}(k)$ を

$$
\mu_{1}(k)=\lambda_{2}(k)
$$

としたとき (A. 1), (A. 2) 式の適応則は (7), (8) 式となり,こ のとき (A. 15) 式の第 3 項を消去できる.

$\Delta V(k)$ 


$$
\begin{aligned}
= & -\left(1-\lambda_{1}(k)\right) \tilde{\theta}^{T}(k+1) F^{-1}(k) \tilde{\theta}(k+1) \\
& -\frac{e^{2}(k) \lambda_{2}(k)}{1+\lambda_{2}(k) \varphi^{T}(k) F(k) \varphi(k)} \\
& -0 \\
& +\lambda_{2}(k) d^{2}(k) \\
= & -\left(1-\lambda_{1}(k)\right) \tilde{\theta}^{T}(k+1) F^{-1}(k) \tilde{\theta}(k+1) \\
& -\frac{\left[e^{2}(k)-(\alpha(k) d(k))^{2}\right] \lambda_{2}(k)}{\alpha^{2}(k)}
\end{aligned}
$$

ただし調整ゲイン $\alpha^{2}(k)(>1)$ を次式で与えた.

$$
\alpha^{2}(k)=1+\lambda_{2}(k) \varphi^{T}(k) F(k) \varphi(k)
$$

簡単のため $\alpha(k)=\alpha=$ const. として (A. 17) 式の第 2 項の 準負を保証するため, 重み係数 $\lambda_{2}(k)$ を次のように定める.

$$
\begin{gathered}
\lambda_{2}(k)=\left\{\begin{array}{cc}
0, & \varphi^{T}(k) \varphi(k)=0 \\
& \text { or }|e(k)| \leq \alpha d_{0}(k) \\
\lambda_{2}^{\prime}(k), & |e(k)|>\alpha d_{0}(k)
\end{array}\right. \\
\lambda_{2}^{\prime}(k)=\frac{\alpha^{2}-1}{\varphi^{T}(k) F(k) \varphi(k)}
\end{gathered}
$$

このとき適応則は $(6)$ (11) 式で与えられる。すると (10),(A. 17) 式より

$$
\Delta V(k) \leq 0
$$

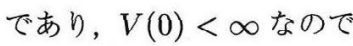

$$
V(k) \leq V(0)<\infty
$$

が成立する。

$$
\begin{gathered}
V(k) \geq 0 \text { と (A. 19) 式より } \\
\lim _{k \rightarrow \infty} V(k)=\text { const. } \\
\lim _{k \rightarrow \infty} \Delta V(k)=0
\end{gathered}
$$

が成り立つ.

$$
\text { (A. 17),(A. 20),(7),(10) 式より }
$$

$$
\begin{aligned}
& \lim _{k \rightarrow \infty} \lambda_{2}(k)=0 \\
& \lim _{k \rightarrow \infty} \theta(k)=\text { const. }
\end{aligned}
$$

が導かれ，目的 $\mathrm{O} 1$ が達成される。さらに仮定 A3と (10),(11),(A. 8),(A. 21) 式より次のように(12),(13) 式を 得る.

$$
\begin{aligned}
& \lim _{k \rightarrow \infty}|e(k)| \leq \alpha \lim _{k \rightarrow \infty} d_{0}(k)=\alpha d_{1}(\because(10),(A .21)) \\
& \leq \alpha \max \left[d_{0}(k)\right] \\
& \lim _{k \rightarrow \infty}\left|\varphi^{T}(k) \tilde{\theta}(k)\right|=\lim _{k \rightarrow \infty}|e(k)-d(k)|(\because(A .8)) \\
& \leq \lim _{k \rightarrow \infty} \alpha d_{0}(k)+\lim _{k \rightarrow \infty} d(k)(\because(12)) \\
& \leq(\alpha+1) \lim _{k \rightarrow \infty} d_{0}(k) \\
& \leq(\alpha+1) \max \left[d_{0}(k)\right]=(\alpha+1) d_{1}
\end{aligned}
$$

時刻 $k=N^{\prime}$ 以降で収束したとき, $\tilde{\theta}(k)=\tilde{\theta}=$ const. $(<\infty)$ となる.さらに仮定 A3 より $p(=n+m+1)$ 元信号べク トル $\varphi(k)$ がP.S. 条件を満たすので $k \geq N^{\prime}$ においてもべ
クトル集合 $\{\varphi(k), \varphi(k+1), \ldots, \varphi(k+M-1)\}$ のランクが $p$ となる $p \leq M(<\infty)$ が存在することから正則な正方行 列 $V_{p}=\left\{\varphi\left(k_{1}\right), \varphi\left(k_{2}\right), \ldots, \varphi\left(k_{p}\right)\right\}, k \leq k_{1}, k_{2}, \ldots, k_{p} \leq$ $k+M-1$ が定義できる.

ゆえに $\tilde{\theta}$ の次数は $p$ なので (13) 式から次式を得る.

$$
\begin{aligned}
\tilde{\theta}^{T}\left(V_{p} V_{p}^{T}\right) \tilde{\theta} & =\left(V_{p}^{T} \tilde{\theta}\right)^{T}\left(V_{p}^{T} \tilde{\theta}\right) \\
& \leq p\left((\alpha+1) d_{1}\right)^{2}
\end{aligned}
$$

$V_{p}$ は正則なので $V_{2}=\left(V_{p} V_{p}^{T}\right)>0$ であり, $V_{2}$ の最小固有 值を $\lambda_{\min }$ とすると

$$
\lambda_{\min } x^{*} x \leq x^{*} V_{2} x
$$

が成立する ${ }^{5)}$

ゆえに(A. 22) 式より $\lambda_{\min } \tilde{\theta}^{T} \tilde{\theta} \leq \tilde{\theta}^{T} V_{2} \tilde{\theta}=\tilde{\theta}^{T}\left(V_{p} V_{p}^{T}\right) \tilde{\theta} \leq$ $p\left((\alpha+1) d_{1}\right)^{2}$ が成り立ち,

$$
\tilde{\theta}^{T} \tilde{\theta} \leq \frac{p\left((\alpha+1) d_{1}\right)^{2}}{\lambda_{\min }}
$$

が成立する。これより次の (14) 式が導かれる.

$$
\|\tilde{\theta}\|_{2} \leq \frac{p^{1 / 2}(\alpha+1) d_{1}}{\max _{V_{p}}\left[\min \left(\operatorname{eig}\left(V_{p} V_{p}^{T}\right)\right)^{1 / 2}\right]}
$$

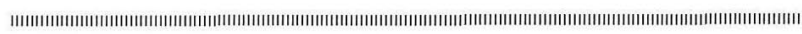

$$
\text { [著 者 紹介] }
$$

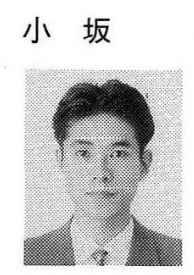

学 (正会員)

1967 年 3 月 29 日生. 1989 年大阪府立大学工 学部電子工学科卒業. 1991 年同大学工学研究科電 子工学専攻博士前期課程修了. 同年 4 月ダイキン 工業（株）入社, 電了技術研究所に勤務し, 現在 に至る。適応制御技術の研究・実用化に従事. シ ステム制御情報学会の会員.

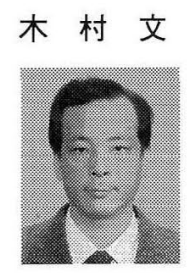

孝 (正会員)

1958 年 7 月 27 日生. 1980 年神戸大学工学部電 気工学科卒業, 1982 年同大学院工学研究科電気. 電子工学専攻博士前期課程修了. 同年 4 月ダイキ ン工業 (株) 入社, 電子技術センター, 電子技術 研究所主任研究員を経て, 現在に至る. 主として 空調機用モー夕制御, 油圧システム制御の研究に 従事. システム制御情報学会, 電気学会, 精密工 学会などの会員.

\section{柴 田浩（正会員）}

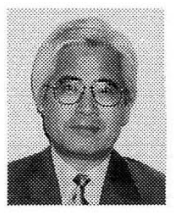

1939 年 7 月 25 日生. 1962 年大阪府立大学工 学部電気工学科卒業, 1 年間富士電気 (株) に勤 務, 63 年大阪府立大学工学部電子工学科助手, 講 師, 助教授を経て 87 年同教授, 94 年改組により 情報工学科教授, 統計的自動制御理論および確率 システムの制御に関する研究を経て, 最近は適応 制御，ロバスト制御，非線形系の制御などの理論 と応用に関する研究に従事. 工学博士. 電子情報 通信学会, 電気学会, 計測自動制御学会, IEEE などの会員 . 